\title{
Effects of problem-based learning on nurse competence: A systematic review
}

\author{
Penelope Cartwright ${ }^{* 1}$, Judith Bruce ${ }^{2}$, Patricia Mclnerney ${ }^{3}$ \\ ${ }^{1}$ Department of Nursing Education, Faculty of Health Sciences, University of the Witwatersrand, Johannesburg, South Africa \\ ${ }^{2}$ School of Therapeutic Sciences, Faculty of Health Sciences, University of the Witwatersrand, Johannesburg, South Africa \\ ${ }^{3}$ Centre for Health Science Education, Faculty of Health Sciences, University of the Witwatersrand, Johannesburg, South Africa
}

Received: September 16, 2016

DOI: $10.5430 /$ jnep.v7n4p67
Accepted: October 23, 2016

Online Published: November 25, 2016

\begin{abstract}
Objective: The aim of this review was to examine studies for evidence of the effects of problem-based learning on the competence of nurses in clinical practice.

Methods: A 5-step systematic review was undertaken as follows: defining the review question, setting the review objectives, searching databases to identify relevant studies between 1999-2009, selecting studies according to set criteria, and extracting and analysing the data. A primary review of 2,815 abstracts led to the selection of 11 studies, identified from a search of eight databases. By consensus review these were narrowed down to five studies: one quantitative and four qualitative. Using the Joanna Briggs SUMARI (System for the Unified Management, Assessment and Review of Information) programme, data were analyzed by meta-synthesis of the qualitative studies and a narrative summary of the quantitative study.

Results: Five studies (two from the USA; two from South Africa; one from Canada) met the inclusion criteria. From the evidence it was found that problem-based learning (PBL) had positive effects on nurse competence. The most commonly identified competencies include problem-solving, critical thinking, self-directedness and independent practice. PBL is instrumental in equipping nurses with leadership skills and the ability to provide high level, quality patient care.

Conclusions: Problem-based learning has positive effects on the development of nurse competence. Supervisors in clinical practice are generally positive about graduates' competence and are inclined to place them in a leadership position in clinical areas.
\end{abstract}

Key Words: Problem-based learning (PBL), Competence, Nurse competence, Systematic review

\section{INTRODUCTION}

Over time, the term "competence" has enjoyed different meanings as a result of the work various scholars. Competence is usually associated with successful performance at an expected level. One of the earliest writings define competence as the "state of having the knowledge, judgement, skills, energy, experience and motivation required to respond adequately to the demands of one's professional responsibili- ties". ${ }^{[1]}$ Educational approaches to achieve desired levels of competence are continuously changing, swopping traditional teaching methods with newer, more progressive ones such as project-based learning, problem-based learning, the flipped classroom and many more. What is not known is whether and how newer methods contribute to the development of nurse competence.

Since the introduction of problem-based learning $(\mathrm{PBL})$ more

\footnotetext{
* Correspondence: Penelope Cartwright; Email: pennycartwright@ telkomsa.net; Address: Department of Nursing Education, Faculty of Health Sciences, University of the Witwatersrand, Johannesburg, South Africa.
} 
than 40 years ago, the competence of nurses in relation to the use of PBL in nurse education is not fully understood. Past reviews have focused on defining what the core competencies of nurses should be during and after their studies. Such core competencies can be described as the ability to apply within a particular profession, the knowledge, abilities, skills, attitudes, values, reasoning and judgement that are required of professionals to perform effectively and competently. ${ }^{[2,3]}$ It is thus mandatory for all nurses to be competent in the delivery of care to patients, using safe and acceptable protocols and methods. ${ }^{[4]}$

However, there is a growing concern about nurse competence-nurses' knowledge levels and skills are said to be lacking at the practical level, which in turn affects their practice and their skills. ${ }^{[5]}$ Bradshaw and Merriman ${ }^{[6]}$ agree that in the last twenty years nurses in the United Kingdom (UK) were found to be deficient in clinical skills. Limitations in nurses' knowledge and its effect on clinical practice demonstrate the gap between knowledge and clinical practice, which begs the question about improved ways of learning in order to bridge this gap. In view of this and an increasing demand for nurses and other health professionals who are self-directed and workplace-ready, progressive curriculum approaches such as PBL have been variously adopted by nursing and medical schools worldwide.

Nursing students who have been exposed to a PBL curriculum are often described as professionals who are competent in the clinical setting from the start of their nursing career, and may even exhibit higher levels of competence compared to their non-PBL peers. ${ }^{[7]}$ This implies that the gap between knowledge and clinical practice could be decreased by using problem-based learning. There are thus two questions that need to be answered in order to know whether nurses are competent in the delivery of care: Are nurses who are educated using a PBL approach able to do this? Does problembased learning actually bridge the gap between knowledge and skills by developing specific competencies? There have been many reviews regarding problem-based programmes in medical education, but limited research has been conducted in the field of nursing. ${ }^{[7]}$ Research on the effects of PBL on nurse competence, in particular, is very limited. The aim of this review was to examine studies for evidence of the effects of problem-based learning on the competence of nurses in clinical practice.

\section{MethodS}

A systematic review was undertaken to identify relevant studies that had been conducted in the field of PBL and the development of nurse competence. A 5-step process was adhered to as follows:

\subsection{Review question}

The review question was formulated based on a search for topics and on questions raised in conversations with stakeholders in nursing education. Through this, an interest developed in problem-based learning and how it affects nurse competence. An initial literature search was undertaken to determine whether any previous systematic reviews had been conducted on the effects of PBL and specifically, the effects on the development of nurse competence. None were found, thus a need was identified to undertake a systematic review to answer the review question: "Is there supporting evidence that problem-based learning has any effect on nurse competence?"

\subsection{Review objectives}

The objectives of this systematic review were to:

- Describe the effects of problem-based learning on the development of nurse competence.

- Describe the competencies most commonly identified in the literature associated with problem-based learning.

\subsection{Study identification}

The identification of studies involves the systematic searching of relevant electronic databases. In order to ensure inclusivity the search included both published and unpublished studies. Furthermore, the reference lists of relevant studies were hand-searched for any other relevant studies that may not have been identified. ${ }^{[8]}$ An initial search of MEDLINE and CINAHL (see Table 1) was conducted over a three-month period using the search terms: "problem-based learning", "nurse competence", "nurse competencies" and "nursing competencies". During the initial search only the titles of the studies were considered and where the titles were unclear, the abstracts were considered. The search terms were refined to include "nursing" and "competenc*" to conduct a secondary search (see Table 2) of the following databases:

- MEDLINE (PUBMED including MeSH)

- CINAHL

- JBI (JBI Database of Systematic Reviews and Implementation Reports)

- SABINET (for published and unpublished studies)

- EBSCO Host-ERIC

- Cochrane Library

- Google Scholar 
Table 1. Initial search of databases and number of studies

\begin{tabular}{lll}
\hline Database & Search term & Number of studies \\
\hline & Problem-based learning & 4484 \\
& Problem-based learning nursing & 759 \\
& Problem-based learning nurse & 377 \\
& Nurse competence & 9149 \\
& Problem-based learning nurse competence & 16 \\
& Problem-based learning nurse competency & 16 \\
& Problem-based learning nurse competencies & 17 \\
& Problem-based learning & 4779 \\
& Problem-based learning nursing & 739 \\
& Problem-based learning nurse & 75 \\
& Nurse competence & 9149 \\
& Problem-based learning nurse competence & 178 \\
& Problem-based learning nurse competency & 29 \\
& Problem-based learning nurse competencies & 23 \\
\hline
\end{tabular}

Table 2. Secondary search of databases and number of studies

\begin{tabular}{|c|c|c|}
\hline Database & Search term & Number of studies \\
\hline \multirow{5}{*}{ MEDLINE (PUBMED) } & Problem-based learning & 7026 \\
\hline & Problem-based learning nursing & 1072 \\
\hline & Problem-based learning nurse & 545 \\
\hline & Nurse competence & 15337 \\
\hline & Problem-based learning nurse competence & 223 \\
\hline \multirow{5}{*}{ JBI } & Problem-based learning & 0 \\
\hline & Problem-based learning nursing & 0 \\
\hline & Problem-based learning nurse & 0 \\
\hline & Nurse competence & 0 \\
\hline & Problem-based learning nurse competence & 178 \\
\hline \multirow{5}{*}{ SABINET } & Problem-based learning & 13 \\
\hline & Problem-based learning nursing & 0 \\
\hline & Problem-based learning nurse & 0 \\
\hline & Nurse competence & 0 \\
\hline & Problem-based learning nurse competence & 0 \\
\hline \multirow{5}{*}{ EBSCO HOST-ERIC } & Problem-based learning & 1041 \\
\hline & Problem-based learning nursing & 2 \\
\hline & Problem-based learning nurse & 385 \\
\hline & Nurse competence & 1 \\
\hline & Problem-based learning nurse competence & 148 \\
\hline \multirow{5}{*}{ COCHRANE LIBRARY } & Problem-based learning & 172 \\
\hline & Problem-based learning nursing & 0 \\
\hline & Problem-based learning nurse & 0 \\
\hline & Nurse competence & 0 \\
\hline & Problem-based learning nurse competence & 10 \\
\hline \multirow{6}{*}{ GOOGLE SCHOLAR } & Problem-based learning & 2470 \\
\hline & Problem-based learning nursing & 799 \\
\hline & Problem-based learning nurse & 1100 \\
\hline & Nurse competence & 11500 \\
\hline & Problem-based learning nurse competence & 504 \\
\hline & Problem-based learning any effect on nurse competence & 275 \\
\hline
\end{tabular}


The initial and secondary search of databases produced a total of 72,591 references. The search strategy and study selection is illustrated in Figure 1.

\subsection{Study selection}

Study selection describes the methods that enable eligible studies to be included according to their relevance and, in the process, it avoids any duplication. ${ }^{[8]}$ Study selection was done firstly, according to the title of the study, followed by reading the abstracts, and lastly, by reading the full text. Studies were selected based on the following inclusion criteria:

- Published and unpublished studies for the period 1999 2009

- Studies that utilized a PBL programme in the education of nurses at entry level into the profession

- Studies that considered nurses one year after graduating from a PBL programme
- Studies that considered cognitive and psychomotor competencies of the qualified nurse

- Studies that were published in the English language

A total of 2,815 abstracts were read by the primary reviewer. Where the abstracts seemed sufficient to meet the inclusion criteria, the reviewer read the full paper. Most studies were not included due to either their titles or abstracts not meeting the inclusion criteria or after critical appraisal, due to the methodological quality of the study. Once selected, the studies were captured in the Joanna Briggs SUMARI (System for the Unified Management, Assessment and Review of Information) programme, ${ }^{[9]}$ consisting of a Qualitative Assessment Review Instrument (QARI) and a Meta Analysis and Statistics Assessment Review Instrument (MAStARI). Primary analysis was done by the primary reviewer resulting in 11 studies $(n=11)$ eligible for the review-several of these were duplicated across databases (see Table 3).

Table 3. Duplication of included studies across databases

\begin{tabular}{|c|c|c|c|c|c|c|c|c|c|}
\hline No & STUDY & CINAHL & $\begin{array}{l}\text { COCH- } \\
\text { RANE }\end{array}$ & ERIC & $\begin{array}{l}\text { GOO- } \\
\text { GLE }\end{array}$ & JBI & $\begin{array}{l}\text { MED- } \\
\text { LINE }\end{array}$ & $\begin{array}{l}\text { PUB- } \\
\text { MED }\end{array}$ & SABINET \\
\hline 1 & $\begin{array}{l}\text { A comparison of competence between } \\
\text { problem-based learning and non-problem-based } \\
\text { graduate nurses }\end{array}$ & $\sqrt{ }$ & & & $\sqrt{ }$ & & & $\sqrt{ }$ & \\
\hline 2 & $\begin{array}{l}\text { Competence of accelerated second degree students } \\
\text { after studying in a collaborative model of nursing } \\
\text { practice education }\end{array}$ & $\sqrt{ }$ & & & $\sqrt{ }$ & & $\sqrt{ }$ & $\sqrt{ }$ & \\
\hline 3 & $\begin{array}{l}\text { Competence of newly qualified registered nurses } \\
\text { from a nursing college }\end{array}$ & & & & $\sqrt{ }$ & & & $\sqrt{ }$ & \\
\hline 4 & $\begin{array}{l}\text { Critical thinking ability of new graduate and } \\
\text { experienced nurses }\end{array}$ & $\sqrt{ }$ & & & $\sqrt{ }$ & & $\sqrt{ }$ & $\sqrt{ }$ & \\
\hline 5 & $\begin{array}{l}\text { Employer perceptions of knowledge, competency, } \\
\text { and professionalism of baccalaureate nursing } \\
\text { graduates from a problem-based programme }\end{array}$ & $\sqrt{ }$ & & & $\sqrt{ }$ & & $\sqrt{ }$ & $\sqrt{ }$ & \\
\hline 6 & $\begin{array}{l}\text { Influence of training experience of Makerere } \\
\text { University medical and nursing graduates on } \\
\text { willingness and competence to work in rural health } \\
\text { facilities }\end{array}$ & & & & $\sqrt{ }$ & & & $\sqrt{ }$ & \\
\hline 7 & $\begin{array}{l}\text { Problem based learning - "bringing everything } \\
\text { together" a strategy for graduate nurse } \\
\text { programmes }\end{array}$ & & & & $\sqrt{ }$ & & & $\sqrt{ }$ & \\
\hline 8 & $\begin{array}{l}\text { Problem-based learning and clinical practice: the } \\
\text { nurse practitioners' perspective }\end{array}$ & & & & $\sqrt{ }$ & & & $\sqrt{ }$ & \\
\hline 9 & Problem-solving competency of nursing graduates & $\sqrt{ }$ & & & $\sqrt{ }$ & & $\sqrt{ }$ & $\sqrt{ }$ & \\
\hline 10 & $\begin{array}{l}\text { The competence of nursing graduates from } \\
\text { problem-based programmes in South Africa }\end{array}$ & $\sqrt{ }$ & & & $\sqrt{ }$ & & $\sqrt{ }$ & $\sqrt{ }$ & \\
\hline \multirow[t]{2}{*}{11} & $\begin{array}{l}\text { The effect of teaching method on long-term } \\
\text { knowledge retention }\end{array}$ & $\sqrt{ }$ & & & $\sqrt{ }$ & & $\sqrt{ }$ & $\sqrt{ }$ & \\
\hline & NUMBER OF STUDIES PER DATABASE & 7 & 0 & 0 & 11 & 0 & 6 & 11 & 0 \\
\hline
\end{tabular}

These studies, six qualitative and five quantitative, underwent independent, critical appraisal by the primary reviewer and co-reviewer using the Joanna Briggs critical appraisal checklists for qualitative and quantitative studies. After appraisal and reviewer consensus five studies $(n=5)$, one quantitative and four qualitative studies, were included in the final review.

\subsection{Data analysis}

Data were analysed by meta-synthesis of the qualitative studies and a narrative summary of the quantitative study. Data 
were extracted from the studies only if they met the inclusion criteria. Data were reviewed by the primary reviewer and then by the co-reviewer against the checklists and relevant data were then extracted using packages from the Joanna Briggs for further analysis. The extraction sheets used were for both qualitative and quantitative data analyzed (QARI and MAStARI respectively). ${ }^{[9]}$ From these programmes the reviewer and co-reviewer independently extracted the data from the studies and made comments. The reviewers extracted the findings from the data analyzed and formed summaries. From the summaries of the studies, categories were formed, which lead to synthesized findings of the systematic review.

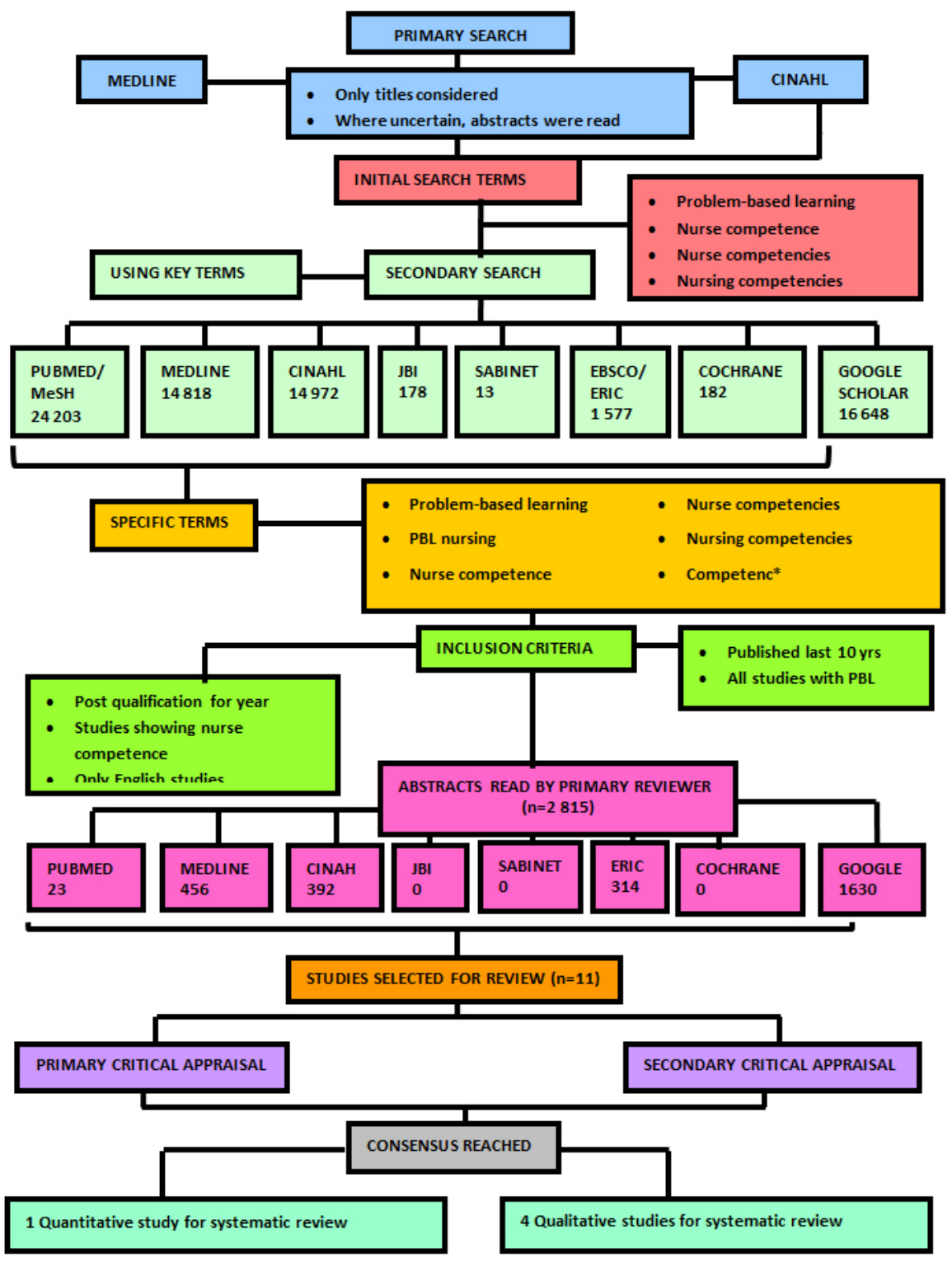

Figure 1. Search strategy and study selection

\section{Results}

Of the five studies that were included, two were conducted in South Africa, two in the United States of America and one in Canada; the majority $(n=4)$ were qualitative studies. The results of the systematic review provided a complete record of all the studies assessed for quality and validity pertaining to the systematic review.

Published by Sciedu Press

\subsection{Meta-synthesis results}

The four qualitative studies contributed to a meta-synthesis where data were extracted from the four studies and 14 relevant findings were identified and merged into four categories. The four categories were reorganized into two main synthesized findings (see Figure 2). 


\begin{tabular}{|c|c|c|}
\hline THEMATIC FINDING & CATEGORY & SYNTHESISED FINDING \\
\hline A new generation of nurse & \multirow{4}{*}{ Feelings of contrast } & \multirow{4}{*}{$\begin{array}{l}\text { Supervisors are generally positive about PBL } \\
\text { graduate competence } \\
\text { Some supervisors of PBL graduates had negative } \\
\text { comments about the graduates but most were } \\
\text { positive. }\end{array}$} \\
\hline Level of practice & & \\
\hline Levels of problem-solving & & \\
\hline Shades of gray & & \\
\hline All-encompassing & \multirow{3}{*}{ Changing thinking } & \multirow{8}{*}{$\begin{array}{c}\text { PBL has positive effects on nurse competence } \\
\text { Graduates from a PBL programme were able to } \\
\text { take on a leadership role and make decisions } \\
\text { more easily. They showed cognitive and } \\
\text { competence and high levels of practice. }\end{array}$} \\
\hline Journeying & & \\
\hline Problem-solving strategies & & \\
\hline Positive incident results & \multirow{5}{*}{$\begin{array}{l}\text { Nurse practice } \\
\text { affirmation }\end{array}$} & \\
\hline Potential to lead us into the future & & \\
\hline Still rough around the edges & & \\
\hline Supervisors' perceptions & & \\
\hline We want them to succeed & & \\
\hline Freedom & \multirow{2}{*}{ Soaring high } & \\
\hline Respondents' feelings & & \\
\hline
\end{tabular}

Figure 2. Results of meta synthesis

The studies detailed the effects of problem-based learning on nurse competence. The evidence showed that problem-based learning, generally, has a positive effect on nurse competence, which in turn produces a nurse who is able to produce quality patient care. PBL produces a new generation of nurses who are skilled in problem-solving, critical thinking and leadership that contrasts their practical skills, which were found to be variable particularly in certain contexts. PBL graduates show higher levels of cognitive competence than those from non-PBL programmes and are thus able to function at a higher level of practice. Table 4 presents a summary of the qualitative findings.

\subsection{Narrative report of quantitative study}

Since there was only one quantitative study ${ }^{[13]}$ selected for data extraction and analysis a meta-analysis could not be done. The study was reviewed and the results were presented using a narrative summary. This study clearly showed that graduates felt they were competent to practice from the outset, but recognized downfalls in certain nursing domains such as psychomotor skills. After six months of practicing in the workplace, all levels of competence increased and the graduates could practice with ease and could demonstrate competence at all levels, including cognitive and psychomotor areas. This was attributed to the graduates having been exposed to a PBL programme.

\section{Discussion}

In this systematic review, both qualitative and quantitative studies were considered for inclusion. Five studies were included in the review and their findings summarized. From the final qualitative results, there were two synthesized findings from the four emerging categories:

\subsection{Employers to supervisors are generally positive about PBL graduates' competence Feelings of contrast}

This category was synthesized from four thematic findings in the studies analysed. These findings include: "a new generation of nurse", "level of practice", "levels of problem-solving" and "shades of gray". These findings describe the feelings of both the practitioners who have a PBL background, and their immediate supervisors while working in the clinical area. Described as "shades of gray" graduates felt that even though they knew what needed to be done in practice, things were never clear cut; however, at the same time PBL equipped them with the skills needed to find answers and solutions. ${ }^{[7]}$ The evidence also shows that PBL enables practitioners to anticipate a problem based on their own assessment of a situation and to act on it with insight - this was termed "levels of problem solving" and "levels of practice". ${ }^{[7,11]}$ Williams and Day ${ }^{[12]}$ showed that graduates from a PBL programme who had practiced skills and established leadership roles in the clinical area could be identified as having behaviours of a "new generation of nurse". 
Table 4. Main findings of qualitative studies

\begin{tabular}{|c|c|c|c|c|c|c|c|}
\hline Study & Design & $\begin{array}{l}\text { Sample/ } \\
\text { Participants }\end{array}$ & $\begin{array}{l}\text { Data } \\
\text { collection }\end{array}$ & Rigor & Data analysis & Main findings & $\begin{array}{l}\text { Level of } \\
\text { evidence }\end{array}$ \\
\hline $\begin{array}{l}\text { Uys, Van } \\
\text { Rhyn, Gwele, } \\
\text { Gwele, } \\
\text { McInerney, } \\
\text { Tanga }^{[7]}\end{array}$ & $\begin{array}{l}\text { Qualitative, } \\
\text { evaluation } \\
\text { study, } \\
\text { descriptive } \\
\text { and } \\
\text { comparative } \\
\text { in nature. }\end{array}$ & $\begin{array}{l}\text { Purposeful sampling. } \\
\text { Graduates from four } \\
\text { universities in South } \\
\text { Africa offering PBL } \\
\text { programmes and } \\
\text { three conventional } \\
\text { programmes in the } \\
\text { same provinces. } \\
\mathrm{n}=49\end{array}$ & $\begin{array}{l}\text { In-depth } \\
\text { interviews } \\
\text { with } \\
\text { graduates and } \\
\text { their } \\
\text { supervisors. }\end{array}$ & $\begin{array}{l}\text { One researcher coded first set of } \\
\text { data \& developed guide for } \\
\text { coding. Second researcher } \\
\text { reviewed coding of first group of } \\
\text { respondents. The two researchers } \\
\text { worked together on first coding } \\
\text { and taught others process. Rest of } \\
\text { researchers met to discuss coding } \\
\text { before final coding done and } \\
\text { report written. }\end{array}$ & $\begin{array}{l}\text { Each researcher } \\
\text { analyzed the data } \\
\text { of one group and } \\
\text { developed } \\
\text { categories. }\end{array}$ & $\begin{array}{l}\text { PBL graduates } \\
\text { tend to function } \\
\text { at a higher level } \\
\text { and are able to } \\
\text { cope in the } \\
\text { clinical setting. }\end{array}$ & 2 \\
\hline Chikotas ${ }^{[10]}$ & $\begin{array}{l}\text { Qualitative, } \\
\text { phenomenolo } \\
\text { gical } \\
\text { exploration }\end{array}$ & $\begin{array}{l}\text { Purposeful sampling. } \\
\text { Snowball effect, } \\
\text { criterion-referenced } \\
\text { sampling. Graduates } \\
\text { from two universities } \\
\text { in United States of } \\
\text { America. } \\
\mathrm{n}=13\end{array}$ & $\begin{array}{l}\text { In-depth, } \\
\text { individual } \\
\text { interviews. } \\
\text { Interview } \\
\text { guide using } \\
\text { open-ended, } \\
\text { semi-structur } \\
\text { ed questions. }\end{array}$ & Member checks done twice. & $\begin{array}{l}\text { Constant } \\
\text { comparative } \\
\text { method to } \\
\text { determine key } \\
\text { themes and } \\
\text { patterns which } \\
\text { were coded and } \\
\text { compared to make } \\
\text { categories. }\end{array}$ & $\begin{array}{l}\text { PBL has a } \\
\text { positive effect } \\
\text { in the practical } \\
\text { environment for } \\
\text { nurse graduates } \\
\text { showing } \\
\text { psychomotor } \\
\text { competence. }\end{array}$ & 2 \\
\hline $\begin{array}{l}\text { Uys, Van } \\
\text { Rhyn, } \\
\text { Gwele, } \\
\text { McInerney, } \\
\text { Tanga }^{[11]}\end{array}$ & $\begin{array}{l}\text { Qualitative, } \\
\text { evaluation } \\
\text { study, } \\
\text { descriptive } \\
\text { and } \\
\text { comparative } \\
\text { in nature. }\end{array}$ & $\begin{array}{l}\text { Purposeful sampling. } \\
\text { Graduates from four } \\
\text { PBL schools and four } \\
\text { non-PBL schools } \\
\text { working in the same } \\
\text { province. } \\
\mathrm{n}=128\end{array}$ & $\begin{array}{l}\text { Interviews } \\
\text { with } \\
\text { open-ended } \\
\text { questions, all } \\
\text { interviews } \\
\text { recorded and } \\
\text { transcribed } \\
\text { verbatim. }\end{array}$ & $\begin{array}{l}\text { Triangulation of sources by } \\
\text { interviewing graduates \& their } \\
\text { employers. } \\
\text { Interviewees were from different } \\
\text { university \& different researcher } \\
\text { transcribed the recorded tapes. }\end{array}$ & $\begin{array}{l}\text { Each researcher } \\
\text { analyzed the data } \\
\text { of one group and } \\
\text { developed } \\
\text { categories. }\end{array}$ & $\begin{array}{l}\text { PBL graduates } \\
\text { are able to } \\
\text { problem-solve } \\
\text { better than } \\
\text { graduates from } \\
\text { a non-PBL } \\
\text { background, } \\
\text { showing } \\
\text { cognitive } \\
\text { competence. }\end{array}$ & 2 \\
\hline $\begin{array}{l}\text { Williams and } \\
\text { Day }^{[12]}\end{array}$ & $\begin{array}{l}\text { Descriptive, } \\
\text { qualitative } \\
\text { study using } \\
\text { focus groups }\end{array}$ & $\begin{array}{l}\text { Purposeful sampling. } \\
\text { Snowball effect - } \\
\text { asking nursing } \\
\text { faculty to identify } \\
\text { from six to eight } \\
\text { graduates from a } \\
\text { PBL programme. } \\
n=53\end{array}$ & $\begin{array}{l}\text { Focus groups } \\
-10 \text { in total }\end{array}$ & $\begin{array}{l}\text { A research assistant managed the } \\
\text { focus groups. Both researcher \& } \\
\text { research assistant met at the end of } \\
\text { the interviews to discuss changes } \\
\text { to interview guide, and verify key } \\
\text { points for validity. } \\
\text { All interviews were taped and } \\
\text { transcribed. }\end{array}$ & $\begin{array}{l}\text { Independent } \\
\text { review of } \\
\text { transcripts and } \\
\text { audio tapes done } \\
\text { by both researcher } \\
\text { and assistant. Then } \\
\text { used coding to get } \\
\text { categories and } \\
\text { eventually themes. }\end{array}$ & $\begin{array}{l}\text { Graduates from } \\
\text { a PBL } \\
\text { programme } \\
\text { have essential } \\
\text { qualities of a } \\
\text { competent } \\
\text { nurse. }\end{array}$ & 2 \\
\hline
\end{tabular}

The evidence suggests that graduates from a PBL background are able to identify and describe incidents better than nonPBL graduates. ${ }^{[7,11]}$ This resulted in problem-solvers who are competent in the clinical environment. Graduates felt confident that PBL gave them the skills necessary to acquire knowledge when confronted with clinical problems, which allowed them to become competent in both psychomotor and cognitive components of competence. ${ }^{[10]}$ Supporting evidence suggests that PBL is a method that facilitates clinical problem-solving, skills development, critical thinking and communication, and that PBL could be linked to graduate satisfaction. ${ }^{[14]}$ PBL also produces graduates who are disciplined and professional, have an assertive attitude, know how to problem solve, are advocates to their patients and are life-long learners. Several authors ${ }^{[7,10,15]}$ concur that problem-based learning is an educational design that allows for the active participation of students and encourages problem-solving and critical-thinking skills. This motivates learning and promotes teamwork, which in turn has a positive effect on competence ensuring a continuously developing and improving nursing professional. ${ }^{[15]}$

\subsection{PBL has positive effects on nurse competence}

\subsubsection{Nurse practice affirmation}

Nurse practice affirmation is based on six thematic findings. These findings include: positive incident results, the potential to lead us into the future, still "rough around the edges", supervisors' perceptions and desires for them to succeed. All the findings in this category confirm nurse competence in practice.

The graduates from the PBL programmes were found to have more positive incidents and outcomes in practice than the non-PBL graduates as they were able to overcome barriers they face. They were more likely to learn from an incident, which had a positive effect on their thinking patterns, in turn resulting in practice affirmation. ${ }^{[7,11]} \mathrm{PBL}$ graduates were also described as "still rough around the edge" as they lacked a few fundamental skills, which they were expected to possess in the first months of practice. From the supervisor's perspective, they were labelled as "task-orientated" due to the fact that they could only focus on the task at hand. ${ }^{[12]}$ PBL graduates were found to be more comfortable in their 
knowledge base than in their clinical skills and were therefore often described by supervisors as lacking in the clinical area, but quickly learnt to improve. ${ }^{[12]}$

\subsubsection{Changing thinking}

This category encapsulates how nurses' thinking processes constantly change and adapt to changing patient and practice circumstances. The findings are described as: "allencompassing", "journeying" and "problem-solving strategies". All the above describes a nurse who has a PBL background and when in a clinical setting, takes all aspects of the patient's life into consideration, allowing the practitioner to manage the patient holistically. This kind of thinking was termed "all-encompassing". ${ }^{[10]}$ A nurse from a PBL programme is able to move from one point to another by using problem-solving skills and is able to reach sound clinical decisions about patients, ${ }^{[10]}$ this aspect of competence is described as "journeying" from one point to the next. This represents a nuanced view that PBL contributes to the development of individual practitioners who are self-directed, who can problem-solve and can make decisions in the clinical area. Uys et al. ${ }^{[11]}$ describe nurses from a PBL background as having "problem-solving strategies" in their suite of competencies, which include using people skills, improvising where necessary, suggesting policy changes, assertiveness and knowing how to access help and resources when needed.

PBL graduates are able to assess, diagnose, treat and manage a patient by approaching the patient holistically, which involves looking at all the facts presented and drawing a conclusion. ${ }^{[10]}$ In this regard PBL is said to increase knowledge and skills in all the steps of the nursing process. ${ }^{[10,16]}$ PBL graduates use people skills to argue or negotiate when communicating with others, which make them leaders in the clinical area, allowing them to make decisions in various situations and showing their assertiveness in a positive manner. ${ }^{[11]}$ PBL graduates are found to possess excellent leadership abilities, which include being advocates for their patients. They can communicate well with the multidisciplinary team, be assertive when needed, prioritise and treat patients correctly, are accountable for their actions and lastly, they are able to conduct research to add to their knowledge and share it with others. ${ }^{[12]}$ Similarly, PBL is said to be effective in improving attitudes towards learning, and has an effect on clinical skills and knowledge development and their ability to impart knowledge. ${ }^{[12,15]}$

\subsubsection{Soaring high}

Based on two findings, "freedom" and "respondents' feelings", this category describes how PBL nursing graduates are able to pursue knowledge at a higher level and with greater independence. Nurses felt that they had the ability to pur- sue knowledge as independent, self-directed learners, and that they were at no point reliant on anyone to provide them with information or to guide them to knowledge sources. ${ }^{[10]}$ PBL allows the graduate to practice in the clinical area with full autonomy and freedom due to the knowledge base they have gained during PBL. Uys et al. ${ }^{[11]}$ describe the "respondents' feelings" where the majority of the PBL graduates felt content with the incidents that they had described in the clinical areas of which they were part. The incidents the graduates described provide them with positive feelings and good outcomes for their patients, and demonstrate a degree of reflective practice. ${ }^{[11]}$

PBL enables a nurse to practice as an independent, selfdirected individual, who is able to conduct research and find answers using various means and resources, and make decisions based on evidence. PBL graduates participate in active learning, which in turn nurtures their critical thinking ability and enables them to investigate and discover other options available when problems are encountered in the clinical area. ${ }^{[15]}$ They are able to think critically due to their exposure to PBL, and this enables them to give quality patient care and makes them leaders in the clinical area. ${ }^{[10,17]}$ Furthermore, PBL is a superior and effective educational approach to prepare competent and skilled practitioners and promote long-term retention of knowledge and skills throughout their learning experience. ${ }^{[17]}$

Results from the quantitative study showed that experiences gained throughout a PBL programme enabled the participants to utilize reflective thinking skills in clinical practice and concluded that there was a relationship between PBL experiences and participants' perceived competence to practice as professional nurses. ${ }^{[13]} \mathrm{PBL}$ is also explicated as a method to develop problem-solving skills and critical thinking, and has an effect on nurses' clinical work and thus patient care. ${ }^{[15]}$ In a 2006 study of a sample of nursing graduates in Canada, the structure and process of PBL was acknowledged as instrumental in them meeting the entry-level competencies. ${ }^{[18]}$

\section{CONClusion}

This review provides evidence that problem-based learning does have an effect on nurse competence, with positive effects outweighing the negative. Nurses exposed to PBL are independent, self-directed, reflective individuals, who become leaders in the clinical area. In light of PBL graduates being task-oriented and low on practical skills, they achieve higher levels of functioning at a holistic level of care sooner than their non-PBL counterparts. The evidence shows that PBL graduates are able to undertake research and find answers to questions, allowing them to gain knowledge at any stage of their career development. Problem-based learning 
prepares nurses to make decisions and solve problems in a systematic manner, which ultimately benefits patients and ensures quality, holistic care of patients.

In addressing the review question there is supporting evidence that problem-based learning has positive effects on nurse competence, both cognitive and psychomotor. Problem-based learning is useful in nursing education programmes as there is supporting evidence of its development of competencies such as problem-solving, critical thinking, communication, self-directedness and leadership. Supervisors in the workplace are generally satisfied with PBL nurses' level of practice and adaptability in changing circumstances. By engendering these competencies, a PBL approach in nurse education may help to bridge the gap between theory and clinical practice.

\section{CONFLicts OF INTEREST Disclosure}

The authors declare that they have no competing interest.

\section{REFERENCES}

[1] Roach. The human act of caring: a blueprint for the health profession (revised edition), Ottawa: Canadian Hospital Association Press; 1992.

[2] Hsu LL, Hsieh SI. Research Methodology Testing of a Measurement Model for Baccalaureate Nursing students' Self Evaluation of Core Competencies. Journal of Advanced Nursing. 2009; 65(11): 24542463. PMid:19761455 https://doi.org/10.1111/j.1365-264 8.2009.05124.x

[3] Lee-Hsieh J, Kao C, Kuo C, et al. Clinical Nursing Competence of RN-to-BSN Students in a Nursing Concept-Based Curriculum in Taiwan. Journal of Nursing Education. 2003; 42(12): 536-546. PMid:14694994

[4] Klein CJ, Fowles ER. An Investigation of Nursing Competence and the Competency Performance Assessment Curricular Approach: Senior Students' Self-Reported Perceptions. Journal of Professional Nursing. 2009; 25(2): 109-121. PMid:19306834 https://doi .or $\mathrm{g} / 10.1016 / \mathrm{j}$. profnurs .2008 .08 .006

[5] Parfitt BA. Evidence-based Practice: The Need for Leadership. Clinical Nursing Research. 2002; 11(5): 5-10. PMid:11845514 https://doi.org/10.1177/105477380201100101

[6] Bradshaw A, Merriman C. Nursing Competence 10 Years on: Fit for Practice and Purpose yet? Journal of Clinical Nursing. 2008; 17: 1263-1269. PMid:18416778 https://doi.org/10.1111/j. $1365-2702.2007 .02243 . x$

[7] Uys L, Gwele N, McInerney P, et al. The Competence of Nursing Graduates from Problem-Based Programs in South Africa. Journal of Nursing Education. 2004b; 43(8): 352-361.

[8] Ng KH, Peh WCG. Effective Medical Writing. Pointers to Getting your Study Published. Writing a Systematic Review. Singapore Medical Journal. 2010; 51(5): 362-366. PMid:20593139

[9] Joanna Briggs Institute. SUMMARI package including: QARI (qualitative assessment and review instrument) and MAStARI. 2009.

[10] Chikotas NE. Problem-Based Learning and Clinical Practice: The Nurse Practitioners' Perspective. Nurse Educator in Practice. 2009;
9: 393-397. PMid:19233724 https://doi.org/10.1016/j.ne pr.2009.01.010

[11] Uys L, Gwele N, McInerney P, et al. Problem-Solving Competency of Nursing Graduates. Journal of Advanced Nursing. 2004a; 48(5): 500-509.

[12] Williams B, Day RA. Employer Perceptions of Knowledge, Competency, and Professionals of Baccalaureate Nursing Graduates from a Problem-Based Program. International Journal of Nursing Education Scholarship. 2009; 6(1): 1-11.

[13] Raines DA. Competence of Accelerated Second Degree Students after Studying in a Collaborative Model of Nursing Practice Education. International Journal of Nursing Education Scholarship. 2009; 6(1): 1-12. Available from: http://www.bepress.com/ijnes/ vol6/iss1/art23

[14] Spiers JA, Williams B, Gibson B, et al. Graduate Nurses' Learning Trajectories and Experiences of Problem Based Learning: A Focused Ethnography Study. International Journal of Nursing Studies. 2014; 51(11): 1462-1471. PMid:24690266 https://doi.org/10.101 $6 / j$. ijnurstu. 2014.03.002

[15] Shin IS, Kim JH. The Effect of Problem-Based Learning in Nursing Education: A Meta-Analysis. Advances in Health Sciences Education. 2013; 18: 1103-1120. PMid:23283571 https://doi.org/10 $.1007 / \mathrm{s} 10459-012-9436-2$

[16] Gholami M, Moghadam PK, Mohammadipoor F, et al. Comparing The Effects of Problem-Based learning and the Traditional Lecture Method on Critical Thinking Skills and Metacognitive Awareness in Nursing Students in a Critical Care Nursing Course. Nurse Education Today. 2016; 45: 16-21. PMid:27429398 https: //doi.org/10.1016/j.nedt.2016.06.007

[17] Yew EHJ, Goh K. Problem-Based Learning: An Overview of its Process and Impact on Learning. Health Professions Education. 2016. http://dx.doi.org.10.1016/j.hpe.2016.01.004

[18] Applin H, Williams B, Day R, et al. A comparison of competencies between problem-based learning and non-problem-based graduate nurses. Nurse Education Today. 2011; 31: 129-134. PMid:20817332 https://doi.org/10.1016/j.nedt.2010.05.003 